\section{The critical success factors for organizational performance of SMEs in Malaysia: a partial least squares approach}

\author{
May Chiun Lo \\ Universiti Malaysia Sarawak, Faculty of Economics and \\ Business, Kota Samarahan, Malaysia \\ Yin Chai Wang \\ Universiti Malaysia Sarawak, Faculty of Computer Science and \\ Information Technology, Kota Samarahan, Malaysia \\ Constance Rinen Justin Wah \\ Universiti Malaysia Sarawak, Faculty of Economics and Business, \\ Kota Samarahan, Malaysia \\ T. Ramayah \\ Universiti Sains Malaysia, School of Management, Minden, Malaysia
}

Received on

03/10/2016

Approved on

06/21/2016

\section{Responsible editor:}

Prof. Dr. João Maurício Gama

Boaventura

\section{Evaluation process:}

Double Blind Review

\begin{abstract}
Purpose - This paper seeks to examine the relationship between the determinants of organizational performance such as top management support, customer focus, employees' orientation, technology orientation, and entrepreneurial orientation in Malaysia.
\end{abstract}

Design/methodology/approach - A quantitative research design was applied for this study. Data was collected through survey questionnaires applied to business owners and senior managers working in SMEs located in three Malaysian states, using purposive sampling technique. SmartPLS 2.0 (M3) was applied to test the hypotheses.

Findings - The findings suggest that both technology and entrepreneurial orientations are significant success factors for SMEs in terms of financial and non-financial performance. In addition, top management support is found to be significantly and positively related to financial performance.

Originality/value - The empirical analysis indicates that technology orientation and entrepreneurial orientation add more value to organizational performance. Therefore, it is vital for SMEs to focus on these two critical success factors in order to improve their performance.

Keywords - Top management support, customer focus, employee orientation, technology orientation, entrepreneurial orientation

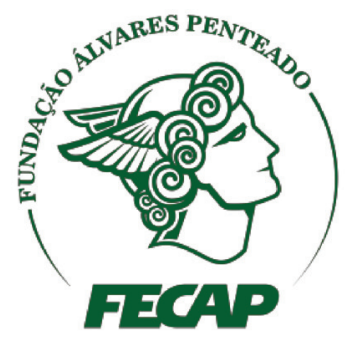

Review of Business Management 


\section{Introduction}

Small and Medium Enterprises (SMEs) are considered as one of the cornerstones of Malaysian's engine of economic growth. Therefore, Malaysian Government has introduced several development programs in helping local SMEs to grow with the intention to realize its vision to be one of the high income nations with developed status by 2020. However, Malaysian SMEs are still losing their competitive advantage in the global business environment due to their low productivity and poor performance (Tehseen, Sajilan, Ramayah, \& Gadar, 2015). Furthermore, Malaysian SMEs are found to provide a lower contribution to the nation's GDP and exports as compared to SMEs of many neighboring nations such as Japan, South Korea, and Singapore (Halim, Ahmad, \& Ramayah, 2013). Taking cognizance of the importance of Malaysian SMEs as the building blocks of economic growth, it is therefore crucial to identify critical success factors that can improve competitiveness and reduce the gap between Malaysian SMEs and SMEs in these countries in term of contribution to the economy.

Prior research has emphasized the importance of various strategic orientations such as technology orientation, learning organization, market orientation, customer orientation, top management support and competitor orientation in determining the firm performance and the development of a sustainable competitive advantage (Day, 1994; Gatignon \& Xuereb, 1997; Zhou \& Li, 2010). In continuation, Salaheldin (2009) proposed a framework to identify the critical success factors of total quality management implementation, and evaluate their effects on operational performance, financial and non-financial performance among the SMEs in Qatari. The results revealed that strategic factors such as leadership, top management support, and organizational culture have strong positive impact on overall performance, while operational factors such as customer orientation, process control, product and service design have a strong positive impact on operational and financial performance, and lastly tactical factors such as supplier relationships, employee training and empowerment have a strong positive impact on operational performance only. Moreover, Chong, Shafaghi, and Tan (2011) critically explored critical success factors for SMEs operating in China and they suggested a combination of internal critical factors (successful customer relationships, security and trust, transparency of information, IS/IT infrastructure, top management support, supply chain facilities) and external critical factors (global competitiveness, government commitments, cultural considerations) in developing and sustaining the success of business to business e-commerce. A recent study conducted by Vyas, Raitani, Roy, and Jain (2015) found that critical success factors such as supportive organizational factors, fast and responsive services, target-based marketing, SME banking policy and model, and enhanced customer services are important for the success of SMEs operating in the banking industry in India.

In view of the above, it is clear that research on critical success factors for SMEs' success is still at a developing stage. Currently, there is still lack of a validated and solid critical success factors framework for SMEs as a guide to improve their competitiveness in the market (Chong, Shafaghi, \& Tan, 2011). This study intends to fill the gap by identifying critical success factors for SMEs in the context of Malaysia, and studying the relationship between identified critical success factors and organizational performance (financial and non-financial performance). The outcome of this study will be useful for entrepreneurs as well as scholars in generating a framework that can improve overall organizational performance in an emerging economic context. The research objectives of this study are twofold:

1. To investigate the relationship between critical success factors (Top Management Support, Customer Focus, Employee Orientation, Technology Orientation, and Entrepreneurial Orientation) and non-financial performance of the SMEs. 
2. To investigate the relationship between critical success factors (Top Management Support, Customer Focus, Employee Orientation, Technology Orientation, and Entrepreneurial Orientation) and financial performance of the SMEs.

The rest of the paper is structured as follows: the first part reviews the existence of empirical literature. Secondly, the research methodology is described. Then, the third part represents the data analysis and respective results. Finally, the results are discussed and conclusions are presented.

\section{Literature review}

This study investigates the relationship between the determinants of organizational performance in SMEs in Malaysia. A review of related literature was undertaken with the primary focus on defining the variables as well as the theoretical relationships between them.

\section{I Organizational performance}

Organizational performance refers to a concept that measures a firm's position in the marketplace and the firm's ability in meeting its stakeholders' needs (Griffin, 2003; Lo, Mohamad, Ramayah, \& Wang, 2015). It can also be known as the degree to which the operation fulfils the performance objectives (primary measures) and meets the needs of the customers (secondary measures) (Slack, Chambers, \& Johnston, 2010).

Previously, the concept of organizational performance normally referred to financial ratios such as profitability, return on assets (ROA), return on investments (ROI), and return on equity (ROE). Nevertheless, there is increasing criticism on the short-term thinking of traditional performance measurement systems that only employs financial measures (Kaplan \& Norton, 1996). Consequently, many researchers have employed a more balanced approach of performance measurement by including both financial performance and non-financial performance measures (Ho, Ahmad, \& Ramayah,
2016; Simon et al., 2015). Financial performance has been seen by many as the ultimate aim of any company and it reflects how well a company uses its assets to generate revenues (Chen, Tsou, \& Huang, 2009). On the other hand, nonfinancial performance measures refer to longterm operational objectives of a company or, in other words, future performance indicators that are not presentable by contemporary financial measures (Blazevic \& Lievens, 2004; Prieto \& Revilla, 2006).

The critical success factors for SMEs are identified by combining literature review and focus group. First, the researcher critically reviewed relevant papers in order to identify critical success factors that have been found to contribute to business success. Then, a focus group consisting of senior executives from the industry was established to rank the identified factors that they perceived as most critical for the success in the current business environment. Among the determinants, five factors have been selected as variables to be studied in this study: top management support, customer focus, employee orientation, technology orientation, and entrepreneurial orientation. These five important determinants of organizational performance serve as the critical success factors for this study.

\subsection{Top management support}

The concept "top management support" has been studied by many scholars and unarguably it is known as one of the most important critical success factors underlying the success of companies (Bryde, 2008; Hung, Lien, Fang, \& McLean, 2010). Top management support refers to backing and commitments by highest ranking executives for projects as well as strategies implementation (Garrett \& Neubaum, 2013).

Flynn, Schroeder and Sakakibara (1995) as well as Powell (1995) likewise argue for the need of top management commitment, as it has a large influence towards the overall strategic direction of the organization. The importance of top management support is further acknowledged 
in the recent empirical literature. General consensus stated that top management support must be verified and demonstrated, by actively communicating the mission and vision throughout the organization (Demirbag et al., 2006; Fotopoulos \& Psomas, 2009; Salaheldin, 2009; Turkyilmaz, Tatoglu, Zaim, \& Ozkan, 2010). Many other aspects should be focused by managers to align the quality objectives with the vision, to commence quality and a corporate culture, and to create a culture with continuous improvements, minimizing the reluctance towards change.

Sexton and Upton (1987) supported the strategic choice perspective by arguing that the performance of a firm is not a natural phenomenon, but rather the choices and social interactions made by the firms' top manager. Top management is empowered with the most influential decision making role in the organization. Furthermore, top management plays a key role in creating conditions in the work environments that are favorable for an integration of learning and work (Noe \& Wilk, 1993). The responsibility of the top management includes communicating the company strategy to all members of the organization, providing financial support for training programs, and motivating employees to innovate and solve problems (Al Shaar, Khattab, Alkaied, \& Manna, 2015; Umble, Haft, \& Umble, 2003). The discussed empirical literatures provide evidence that displaying top management support is essential, and how it remains critical in order to reap the benefits. In this regard, Iqbal, Long, Fei, Ba'ith, and Bukhari (2015) revealed that top management support plays a crucial role in ensuring project success by facilitating the provision of timely resources. Similarly, Fernandes, Lourenço, and Silva (2014) found that leadership attitude and support of the top management can promote organizational innovation. Therefore, the following hypotheses are formulated:

H1: Top management support is positively related to non-financial performance.
H2: Top management support is positively related to financial performance.

\subsection{Customer focus}

Customer focus is similar to market orientation, both looking for innovative solutions that can create superior customer value. However, customer focus and market orientation are different to those businesses that actively attempt to understand their markets (Slater \& Narver, 1998). Customer focus places the customer as the top of the organizational chart, whereas market orientation gives equal weight to customer needs, competitive context, and inter-functional coordination (Narver \& Slater, 1990).

Having a customer focus is essential as it is known as a strong contributor to business profitability, competitive advantage, and a hallmark of successful business (Nwokah \& Maclayton, 2006; Ziggers \& Henseler, 2015). Also, the construct of customer focus is vital for the organization relationship as it refers to the process of identifying and establishing, maintaining, enhancing and when necessary terminating relationships with customers and other stakeholders (Gronroos, 2004). Today's business entrepreneurs must always make sure that they have a strong customer focus so that they are able to respond to rapid changing customer preferences and needs (Saravanan \& Rao, 2006).

In general, firms' profits result from how well the customer needs and wants are satisfied, the path from customer focus and firm profitability is often not straightforward as it becomes evident based on the mixed empirical findings in the literature (Noble, Sinha, \& Kumar, 2002). According to Fernandes, Lourenço, and Silva (2014), it requires efforts on identifying customer current as well as future needs in order to offer products adapted to the evolution of market requirements. In determining the quality, customer is regarded as the king in the organization (Deming, 1986). As a facet of the organizational strategy (Gatignon \& Xuereb, 1997), customer focus provides a basis for 
obtaining customer information, which can be used to develop and deploy supply-chain relationship capabilities, referring to the stock of knowledge-based competencies for effective managing a firm (Chen, Paulraj, \& Lado, 2004; Kirca, Jayachandran, \& Bearden, 2005; Liu, Ke, Wei, \& Hua, 2013). The support of having a high degree of customer focus in SMEs is likewise addressed in the study conducted by Ahire and Golhar (1996), who further argue that the focus of customers may be stronger in SMEs due to their proximity to and close relationship with the customers. The SMEs' organizations should not view customers only as a source of firm's revenues and profits, but also as resources for gaining and sustaining competitive advantage. Therefore, the following hypotheses are proposed:

H3: Customer focus is positively related to non-financial performance.

H4: Customer focus is positively related to financial performance.

\subsection{Employee orientation}

Employee orientation or employee focus is in numerous studies referred to as one of the most important factors underlying a successful employment. Employee orientation can be defined as the familiarization with a new work environment. The first few months are a critical period for employees to perform and become a high performer. Many managers view the employee orientation as a very mechanical information gathering exercise (Bernardin \& Russell, 1993). Sharing internal and external information across functional groups can encourage employees to feel more responsible for quality decision and improvements. Sun (2000) argued that the essence of involving employees in the decision making process or empowerment is that the employees nearest a potential opportunity or a problem are in the best position of making the necessary decisions, if they have control over the process. Ensuring an efficient flow of feedback is thus essential to remove barriers to performance improvements. As stated by Yusof and Aspinwall (2000), SMEs often have flattened organizational structure and a shorter decision making process, enabling a faster information flow and improved communication. Apart from engaging employees with empowerment, continuous education and training are essential for the sustainability of their personal and organizational growth. As the provision of employees training and empowerment is associated with costs of the organization, it must be aligned with employee's evaluations in order to examine the effectiveness of the event (Hendricks \& Singhal, 1997).

Employee orientation is imperative for better organizational performance as it can create higher level of job satisfaction and employee retention while decreasing employee's turnover rate (Awan, 2013). Firms which display high level of employee orientation will gain trust and appreciation from employees that ultimately lead them to perform and achieve better financial performance than others (de Bussy \& Suprawan, 2012). Therefore, the following hypotheses are developed:

H5: Employee orientation is positively related to non-financial performance.

H6: Employee orientation is positively related to financial performance.

\subsection{Technology orientation}

Technology orientation aids firms in acquiring a substantial technological background and using it to come out with new solutions in response to their customer needs (Gatignon \& Xuereb, 1997; Grinstein, 2008). Therefore, it is often known as the fundamental source of sustainable competitive advantage. Previous researchers stated that consumers prefer products and services that maintain technological superiority (Zhou, Yim, \& Tse, 2005). Therefore, technology-oriented firms which have ability to accumulate rich technological information 
through R\&D intensity as well as to quickly adapt to new technologies have an increased chance of achieving superior performance (Zhou $\& \mathrm{Li}$, 2010).

Furthermore, invention and creativity in adopting technology may provide the guidelines to the firms on what strategic implementation to be executed. SMEs that focus on technology leadership offers advanced products difficult to be imitated by their competitors, thus increasing the switching costs. Therefore, technology orientation is linked to enhance new product success and profitability (Gatignon \& Xuereb, 1997; Song \& Parry, 1997; Trainor, Rapp, Beitelspacher, \& Schillewaert, 2010). Moreover, a number of researchers found a significant and positive relationship between technology orientation and innovation (Al-Ansari, Altalib, \& Sardoh, 2013; Lee, Choi, \& Kwak, 2015). On the other hand, Gatignon and Xuereb (1997) recommended firms to foster technology orientation in both high and low market growth situations for a competitive advantage in product development. Although high technology-applied solutions are presented, sometimes the customers could not benefit from the implementation. If the firm failed to adapt the advanced technology into customers' benefits, the business performance of the firms could not happen. Therefore, any high technology adaptation should align with the high organizational performance. Based on the literatures discussed above, the following hypotheses have been formulated:

\section{H7: Technology orientation is positively related to non-financial performance.}

H8: Technology orientation is positively related to financial performance.

\subsection{Entrepreneurial orientation}

Entrepreneurism is an essential role in the society, performing businesses and contributing towards the growth of organizational performance. Due to the changing environment in which most organizations are now competing, it is essential to consider the importance of top managers from the standpoint of how their entrepreneurial preferences and value may impact decision making. Entrepreneurial orientation refers to tendencies, processes and behaviors that lead to new markets (or existing) goods or services via the existing (or new) ones (Walter, Auer \& Ritter, 2006). At the organization level, entrepreneurial orientation is defined as the strategy making processes that provide organizations with a basis for entrepreneurial decision and actions (Rauch, Wiklund, Lumpkin, \& Frese, 2009). On the other hand, Lumpkin and Dess (1996) stated that entrepreneurial orientation is said to be a company's strategic orientation, having certain entrepreneurial aspects, styles, methods and decision attributes (Wiklund \& Shepherd, 2005). Based on different models of corporate entrepreneurship, entrepreneurial orientation includes five features such as innovativeness, riskiness, proactiveness, competitive aggressiveness and autonomy (Walter et al., 2006). Apart from that, innovativeness has been considered as one of the most important strategic orientations of firms to achieve long-term success (Noble et al., 2002), and having a significant effect on venture performance (Baum, 1995; Rauch \& Frese, 2000; Utsch \& Rauch, 2000).

Entrepreneurial orientation is crucial as it captures the process through which organizations explore opportunities for new innovations leading to market entry and advantage (Covin \& Miles, 1999; Lumpkin \& Dess, 1996). It represents an important means through which firms identify new opportunities and take calculated risks to innovate for growth and renewal (Ireland, Hitt, \& Sirmon, 2003; Wales, Parida, \& Patel, 2013). A significant amount of strategy research has focused on the importance of top management (Hambrick \& Mason, 1984) and entrepreneurial behavior (Covin \& Slevin, 1989) in determining firm performance. It has been studied predominantly in its relation to the firm performance and has been consistently shown to be highly significant 
(Gupta \& Batra, 2015). In a meta-analysis of 51 studies, Rauch et al. (2009) observed a generally positive and moderately large $(r=0.242)$ correlation between entrepreneurial orientation and firm performance across measures of both growth and profitability. Furthermore, Jabeen and Mahmood (2014) elucidate that firms who adopt entrepreneurial orientation can frequently innovate and are willing to take risks in their strategies that ultimately leads them to superior performance. Based on these discussions, the following hypotheses have been developed:

H9: Entrepreneurial orientation is positively related to non-financial performance.

H 10: Entrepreneurial orientation is positively related to financial performance.

\section{Methodology}

A quantitative research design was applied for this study. The population of this study consists of business owners and senior managers currently working in SMEs in the states of Selangor, Kuala Lumpur, and Sarawak. In selecting the respondents, we adopted a method of purposive sampling. SME directory provided by SME Corporation Malaysia was utilized to determine the sample that meet the following inclusion criteria: (1) the firm must have less than 200 full time employees for the manufacturing sector and 75 full time employees for the service sector; and (2) the firm must be a standalone firm, not a franchise or part of a larger organization.

The measuring instrument for data collection was in the form of a questionnaire, and all scales were adapted from previous studies which validated them in the contexts of developed as well as developing economies. The questionnaire was divided into three sections. Section 1 required the respondents to rate a total of 25 items on five critical success factors, namely top management support, customer focus, employee orientation, technology orientation, and entrepreneurial orientation. For the purpose of this study, the items for measuring top management support were adapted from the work by Ar and Baki (2011). As for customer focus, items by Das, Paul, and Swierczek (2008) were adapted. In addition, the items for another three critical success factors, namely employee orientation, technology orientation, and entrepreneurial orientation, were adapted from the work by Zhang (2010), Kim, Im, and Slater (2013), and $\mathrm{Mu}$ and Benedetto (2011) respectively. Section 2 required respondents to assess their perceived non-financial performance as well as financial performance. Non-financial performance measures were adapted from studies by Aron and Liem (2011), Zebal and Goodwin (2011), Lee, Kim, and Choi (2012), Chong, Chan, and Sim (2011), and Vazquez, Silva, and Ruiz (2012). On the other hand, financial performance measures were drawn from previous empirical studies such as those by Ganeshasundaram and Henley (2007), Slater, Hult, and Olson (2010), and Zebal and Goodwin (2011). All of the items in Section 1 and Section 2 are anchored on a Likert scale of 7 -points $(1=$ strongly disagree and $7=$ strongly agree). Lastly, Section 3 covers the personal profile and demographic data of respondents.

Before data collection, a pre-test through personal interview with 15 senior executives of SMEs was conducted to check whether the questions were clearly understood by the respondents and to determine if any further modification of the items and format was necessary. After refining the wording of some of the measures, a total of 500 questionnaires were distributed personally to selected SMEs. Initially, the researcher visited the selected SMEs to get the approval from the SMEs to conduct the survey. After a brief personal communication concerning the topic and the goals of the study, the questionnaires, together with the cover letters seeking their cooperation and explaining the purpose of the study as well as self-addressed envelopes for the completed questionnaires, were all personally handed to the respondents. The researcher ensured the anonymity of respondents 
before they participated in the survey in order to reduce socially desirable responses. Out of the 500 distributed questionnaires, 180 questionnaires were returned and used for statistical analysis, indicating a response rate of $36 \%$.

Data was collected from a single informant in each SME, and thus common method variance could potentially have affected the results. Following Podsakoff, MacKenzie, Lee, and Podsakoff's (2003) suggestion, Harman's singlefactor test was used as a diagnostic to assess the risk. The results revealed five distinct factors that accounted for $72.28 \%$ of the total variance, with the largest factor accounting for only $46.94 \%$ of the variance. Consequently, it can be concluded that common-method variance is not likely to be a significant problem in this study.

Data were analyzed using Statistical Package for Social Sciences (SPSS) 20.0 and SmartPLS 2.0 developed by Ringle, Wende, and Will (2005). Partial Least Squares (PLS) were employed as it presents the benefit of permitting the complete research model to be tested just once (Halawi \& McCarthy, 2008). First, the demographic profiles of the respondents were analyzed by using descriptive statistics in SPSS. Then, the SmartPLS 2.0 which is based on path modeling and bootstrapping (Chin, 1998; Tenenhaus, Esposito Vinzi, Chatelin, \& Lauro, 2005; Wetzels, Odekerken-Schroder, \& van Oppen, 2009) was used to measure the model as shown in Figure 1. The analysis in PLS was divided into two stages: measurement model and structural model. Measurement model involves the assessment of the reliability and validity of the measures. In the measurement model, reliability was assessed by examining the Composite Reliability (CR) while validity was assessed in convergent validity and discriminant validity. Once the measurement model was done, structural model testing with 500 re-samples was applied to test the hypothesized relationships between critical success factors and organizational performance.

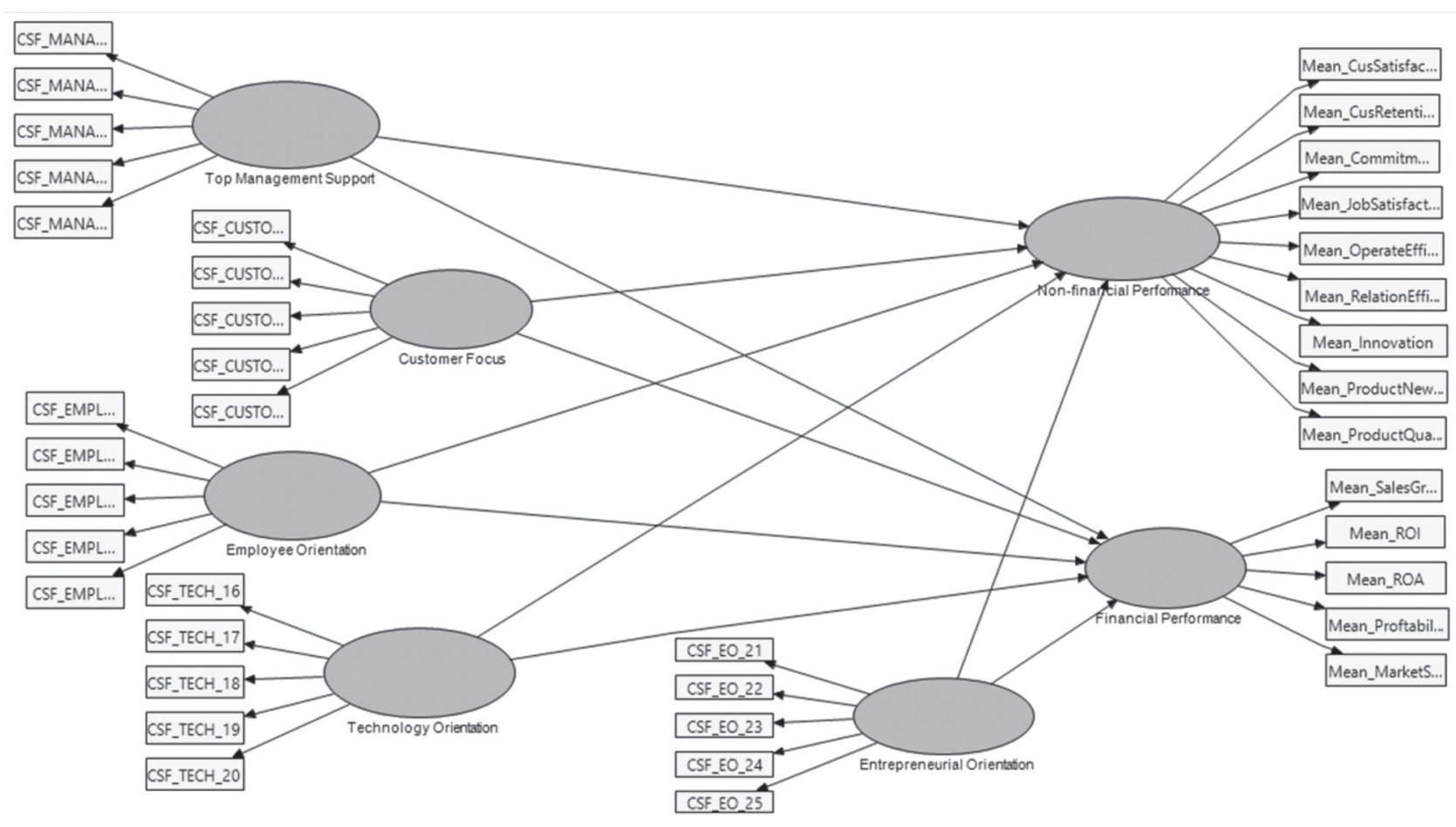

Figure 1. Research model 


\section{Findings}

\section{I Respondent profile}

Table 1 shows the demographic information of the 180 respondents. The number of female respondents was higher than male respondents with 94 female respondents $(52.2 \%)$ and 86 male respondents $(47.8 \%)$. The majority of the respondents held degree or professional qualification (108 or 60\%), followed by diploma (32 or $17.8 \%$ ), postgraduate ( 24 or $13.3 \%)$, and high school or below (16 or $8.9 \%$ ). In terms of industry, $30(16.7 \%)$ of them were from manufacturing industry and 150 (83.3\%) were from service industry. Most of the firms which responded have between 3-75 employees (125 or $69.5 \%), 29$ (16.1\%) firms have less than 5 employees, and 26 (14.4\%) firms have more than 75 employees. With regard to the year of establishment, 74 (41.1\%) firms were established for 2 years or less, 64 (35.6\%) firms were established for between 3 to 5 years, 28 (15.6\%) firms were established for between 6 to 10 years, and only $14(7.8 \%)$ firms were established for 11 years or more. Most of the respondents of the survey were senior manager (141 or $78.3 \%$ ), followed by business owner (39 or $21.7 \%$ ).

Table 1

\section{Demographic profile of respondents}

\begin{tabular}{|c|c|c|c|}
\hline \multirow{2}{*}{ Demographic variables } & \multirow{2}{*}{ Category } & \multicolumn{2}{|c|}{ Respondents ( $\mathrm{N}=180)$} \\
\hline & & Frequency & Percentage $(\%)$ \\
\hline \multirow[t]{2}{*}{ Gender } & Male & 86 & 47.8 \\
\hline & Female & 94 & 52.2 \\
\hline \multirow[t]{4}{*}{ Academic qualification } & High school or below & 16 & 8.9 \\
\hline & Diploma & 32 & 17.8 \\
\hline & Degree or professional qualification & 108 & 60.0 \\
\hline & Postgraduate & 24 & 13.3 \\
\hline \multirow{2}{*}{ Industry } & Manufacturing & 30 & 16.7 \\
\hline & Service & 150 & 83.3 \\
\hline \multirow[t]{3}{*}{ Number of employees } & Less than 5 & 29 & 16.1 \\
\hline & Between 5 and 75 & 125 & 69.5 \\
\hline & More than 75 & 26 & 14.4 \\
\hline \multirow{4}{*}{ Years of establishment } & 2 years or less & 74 & 41.1 \\
\hline & 3 to 5 years & 64 & 35.6 \\
\hline & 6 to 10 years & 28 & 15.6 \\
\hline & 11 years or more & 14 & 7.8 \\
\hline \multirow[t]{2}{*}{ Position in the company } & Business owner & 39 & 21.7 \\
\hline & Senior manager & 141 & 78.3 \\
\hline
\end{tabular}

\subsection{Assessment of the measurement model}

Firstly, confirmatory factor analysis (CFA) was conducted to test the reliability, convergent validity, and discriminant validity of the measures. Hair, Black, Babin, and Anderson (2010) suggested the use of factor loadings, Average Variance Extracted (AVE), and Composite Reliability (CR) to assess convergent validity. As indicated in the Table 2, most item loadings were close to or larger than 0.5 (significant at $\mathrm{p}<0.01$ ), all Average Variance Extracted (AVE) exceeded 0.5 (Bagozzi \& Yi, 1988), and the Composite Reliability (CR) for all the variables exceeded 0.7 (Gefen, Straub, \& Boudreau, 2000).

In addition, the square root of the AVE was tested against the intercorrelations of the construct with the other constructs in the model to ensure discriminant validity (Chin, 1998, 2010; Fornell \& Larcker, 1981) and, as indicated in Table 3, all the square roots of the AVE 
exceeded the correlations with other variables.

Thus, the measurement model was considered satisfactory with the evidence of adequate reliability, convergent validity, and discriminant validity.

\section{Table 2}

\section{Result of measurement model}

\begin{tabular}{|c|c|c|c|}
\hline Construct & Loadings & $\mathbf{C R}^{\mathrm{a}}$ & $\mathrm{AVE}^{\mathrm{b}}$ \\
\hline Top Management Support & & 0.915 & 0.687 \\
\hline $\begin{array}{l}\text { CSF_MANAGERSUPPORT_1: Top management researches the new technologies, processes } \\
\text { and product ideas. } \\
\text { CSF_MANAGERSUPPORT_2: Top management actively seeks innovative ideas. } \\
\text { CSF_MANAGERSUPPORT_3: Top management encourages innovation activities. } \\
\text { CSF_MANAGERSUPPORT_4: Top management promotes the advantages of new solutions } \\
\text { and ideas enthusiastically. } \\
\text { CSF_MANAGERSUPPORT_5: Mistakes regarding creative and innovative efforts of } \\
\text { individuals are tolerated by top management. }\end{array}$ & $\begin{array}{l}0.835 \\
0.870 \\
0.902\end{array}$ & & \\
\hline Customer Focus & & 0.900 & 0.643 \\
\hline $\begin{array}{l}\text { CSF_CUSTOMER_6: Our company has developed a program to maintain good customer } \\
\text { communication. } \\
\text { CSF_CUSTOMER_7: Our company collects extensive complaint information from } \\
\text { customers. } \\
\text { CSF_CUSTOMER_8: Quality-related customer complaints are treated with top priority. } \\
\text { CSF_CUSTOMER_9: Our company conducts a customer satisfaction survey every year. } \\
\text { CSF_CUSTOMER_10: Our company always conducts market research for collecting } \\
\text { suggestions for improving our products. }\end{array}$ & $\begin{array}{l}0.812 \\
0.814 \\
0.845 \\
0.794 \\
0.740\end{array}$ & & \\
\hline $\begin{array}{l}\text { Employee Orientation } \\
\text { CSF_EMPLOYEE_11: In our company, people are rewarded in the proportion to the } \\
\text { excellence of their job performance. } \\
\text { CSF_EMPLOYEE_12: Our company has a promotion system that helps the best persons to } \\
\text { rise to the top. } \\
\text { CSF_EMPLOYEE_13: Our company is characterized by a relaxed, easygoing working } \\
\text { climate. } \\
\text { CSF_EMPLOYEE_14: There is a lot of warmth in the relationships between management } \\
\text { and workers in this company. } \\
\text { CSF_EMPLOYEE_15: The philosophy of our management emphasizes the human factor, } \\
\text { how people feel, etc. }\end{array}$ & $\begin{array}{l}0.761 \\
0.843 \\
0.616 \\
0.832 \\
0.821 \\
\end{array}$ & 0.884 & 0.607 \\
\hline $\begin{array}{l}\text { Technology Orientation } \\
\text { CSF_TECH_16: Our company uses advanced technologies in new product development. } \\
\text { CSF_TECH_17: Our company uses the latest technologies in new product development. } \\
\text { CSF_TECH_18: Our products are on the leading edge of the industry standard. } \\
\text { CSF_TECH_19: Our company uses systematic scanning for new technologies inside and } \\
\text { outside the industry. } \\
\text { CSF_TECH_20: Our company reinvests a significant portion of profit in R\&D. }\end{array}$ & $\begin{array}{l}0.805 \\
0.844 \\
0.875 \\
0.900 \\
0.817 \\
\end{array}$ & 0.928 & 0.721 \\
\hline $\begin{array}{l}\text { Entrepreneurial Orientation } \\
\text { CSF_EO_21: Our company has built capacity to react to market changes. } \\
\text { CSF_EO_22: Our company protects our advantages from industry changes. } \\
\text { CSF_EO_23: Our company prepares for radical industry changes. } \\
\text { CSF_EO_24: Our company believed that wide-ranging acts were necessary to achieve } \\
\text { objectives. } \\
\text { CSF_EO_25: Our company initiated actions to which other organizations respond. }\end{array}$ & $\begin{array}{l}0.871 \\
0.910 \\
0.899 \\
0.788 \\
0.859\end{array}$ & 0.938 & 0.751 \\
\hline
\end{tabular}




\begin{tabular}{lcc}
\hline Construct & Loadings $^{-\mathbf{C R}^{\mathbf{a}}}$ & $\mathbf{A V E}^{\mathbf{b}}$ \\
\hline Non-financial Performance & 0.752 & 0.956 \\
Mean_CusRetention & & \\
We have more repeat sales in our company. & \\
It is easy to see repeat clients in our company. & \\
If a client trade with us at least once, he/she remains with us forever. &
\end{tabular}

Mean_CusSatisfaction

Our company ensures that customers' product and/or service preferences are satisfied.

Our company delivers products and/or services that are exactly what customers want.

Our company delivers products and/or services that exceed customers' expectations.

Mean_Commitment

Our employees would be happy to make personal sacrifices if it is too important for the company's well being.

The bonds between our company and our employees are strong.

Our employees have little or no commitment to this company.

Mean_JobSatisfaction

Most of our employees like their jobs in this company.

Most of our employees think their supervisor treats them well.

Most of our employees do not intend to work for a different company.

Overall, our employees are quite satisfied with their jobs.

Mean_OperateEfficiency

Our product development cycle time has been reduced.

Overall, our product development costs have been reduced.

Our project duration has been reduced.

Mean_RelationEfficiency

Our company has more open sharing of information with our customers.

Our company has a more effective working relationship with our customers.

Our company has an enhanced commitment to work with our customers in the future.

Our company has an overall more productive working relationship with our customers.

Mean_Innovation

Our company is fast in adopting process with the latest technological innovations.

Our company uses up-to-date or new technology in the process.

Our company has enough new products introduced to the market.

Our company is able to produce products with novelty features.

Mean_ProductNewness

It required a major learning effort or experience by customers to use our product.

It took a long time before customers could understand our product's full advantages.

The product/service concept was difficult for customers to evaluate or understand.

Mean_ProductQuality

The quality of our products/services compares well with competitor products.

Our products/services are of higher quality than competing products/services.

The quality of our current products/services compares well with others we have offered in the past. 


\begin{tabular}{|c|c|c|c|}
\hline Construct & Loadings & $\mathrm{CR}^{\mathrm{a}}$ & $\mathrm{AVE}^{\mathrm{b}}$ \\
\hline $\begin{array}{l}\text { Financial Performance } \\
\text { Mean_ROA } \\
\text { Our company generates a relatively higher return on assets than our competitors do. } \\
\text { Our business unit has a cost advantage compared to our major competitor. }\end{array}$ & 0.870 & 0.925 & 0.585 \\
\hline $\begin{array}{l}\text { Mean_ROI } \\
\text { Our company is highly effective in terms of capital investments. } \\
\text { The return on investment of our company has improved over the past three years. }\end{array}$ & 0.906 & & \\
\hline $\begin{array}{l}\text { Mean_SalesGrowth } \\
\text { Our company has remarkable customer growth over the past three years. } \\
\text { The sales volume of our product offerings has increased over the past three years. }\end{array}$ & 0.923 & & \\
\hline $\begin{array}{l}\text { Mean_MarketShare } \\
\text { Our company is more effective in opening up new markets or expanding existing markets } \\
\text { than our competitors. } \\
\text { Our company is able to change the market or lead customers' needs in new directions. }\end{array}$ & 0.911 & & \\
\hline $\begin{array}{l}\text { Mean_Proftability } \\
\text { The profit of our company grew over the past three years. } \\
\text { Our company achieves higher profit margins, even when charging comparable prices, than } \\
\text { our major competitors. }\end{array}$ & 0.895 & & \\
\hline
\end{tabular}

Notes: ${ }^{a}$ Composite Reliability $(\mathbf{C R})=$ (square of the summation of the factor loadings) $/$ (square of the summation of the factor loadings) + (square of the summation of the error variances)

${ }^{\mathrm{b}}$ Average Variance Extracted (AVE) $=$ (summation of the square of the factor loadings)/\{( summation of the square of the factor loadings) + (summation of the error variances.

Table 3

Discriminant validity of constructs

\begin{tabular}{|c|c|c|c|c|c|c|c|}
\hline Construct & $\begin{array}{l}\text { Customer } \\
\text { Focus }\end{array}$ & $\begin{array}{c}\text { Employee } \\
\text { Orientation }\end{array}$ & $\begin{array}{c}\text { Entrepreneurial } \\
\text { Orientation }\end{array}$ & $\begin{array}{c}\text { Financial } \\
\text { Performance }\end{array}$ & $\begin{array}{l}\text { Non-financial } \\
\text { Performance }\end{array}$ & $\begin{array}{l}\text { Technology } \\
\text { Orientation }\end{array}$ & $\begin{array}{c}\text { Top } \\
\text { Management } \\
\text { Support }\end{array}$ \\
\hline Customer Focus & 0.802 & & & & & & \\
\hline Employee Orientation & 0.680 & 0.779 & & & & & \\
\hline $\begin{array}{l}\text { Entrepreneurial } \\
\text { Orientation }\end{array}$ & 0.569 & 0.631 & 0.867 & & & & \\
\hline Financial Performance & 0.459 & 0.470 & 0.568 & 0.901 & & & \\
\hline $\begin{array}{l}\text { Non-financial } \\
\text { Performance }\end{array}$ & 0.505 & 0.548 & 0.601 & 0.818 & 0.765 & & \\
\hline $\begin{array}{l}\text { Technology } \\
\text { Orientation }\end{array}$ & 0.643 & 0.678 & 0.617 & 0.613 & 0.645 & 0.849 & \\
\hline $\begin{array}{l}\text { Top Management } \\
\text { Support }\end{array}$ & 0.687 & 0.612 & 0.469 & 0.325 & 0.464 & 0.543 & 0.829 \\
\hline
\end{tabular}

Note: Diagonals (in bold) represent the square root of the average variance extracted while the other entries represent the correlations. 


\subsection{Assessment of the structural model}

Secondly, Figure 2 and Table 4 present the results of the hypotheses testing. It was revealed that three hypotheses were found to be significantly related to the attitudes. The results have revealed that three hypotheses, namely, $\mathrm{H} 2$, $\mathrm{H} 7, \mathrm{H} 8, \mathrm{H} 9$, and $\mathrm{H} 10$ were supported whereas H1, H3, H4, H5, and H6 were not supported.

We also conducted a global fit measure (GoF) assessment for PLS path modeling, which is defined as the geometric mean of the average communality and average $\mathrm{R}^{2}$ for endogenous constructs (Tenenhaus et al., 2005) following the procedure used by Akter, D'Ambra and Ray (2011). Following the guidelines of Wetzels et al. (2009), we estimated the GoF values which may serve as cut-off values for global validation of PLS models. The GoF value of 0.566 (average $\mathrm{R}^{2}$ was 0.466 , average AVE was 0.687) for the (main effects) model, which exceeds the cut-off value of 0.36 for large effect sizes of $\mathrm{R}^{2}$. As such, it allows us to conclude that our model has better explaining power in comparison with the baseline values $\left(G o F_{\text {small }}=0.1, G o F_{\text {medium }}=0.25, G o F_{\text {large }}=0.36\right)$ (Akter et al., 2011). It also provides adequate support to validate the PLS model globally (Wetzels et al., 2005).

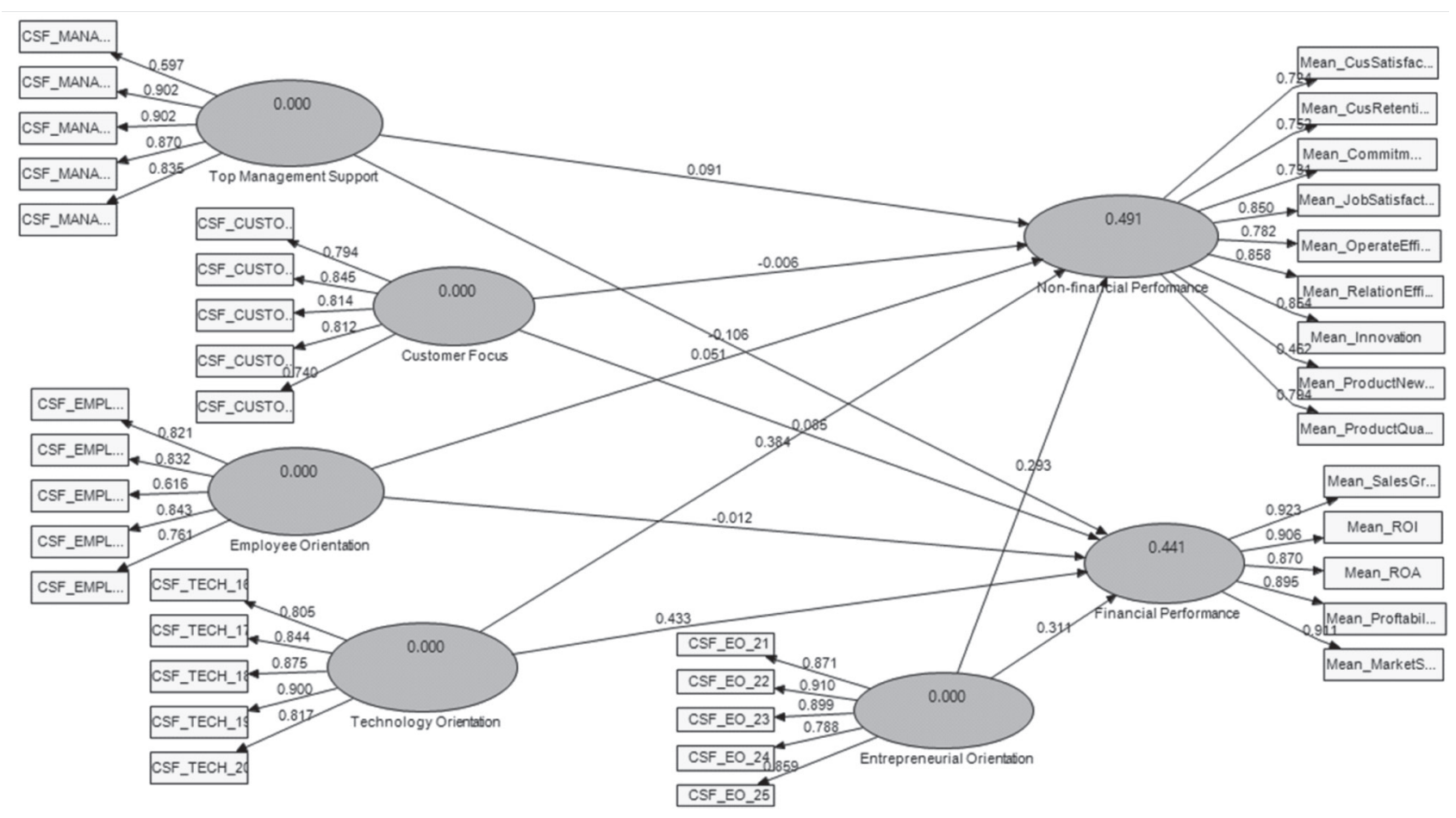

Figure 2. Results of the path analysis 
Table 4

Path coefficients and hypothesis testing

\begin{tabular}{|c|c|c|c|c|c|}
\hline Hypothesis & Relationship & Standard Beta & Standard Error & t-value & Supported \\
\hline $\mathrm{H} 1$ & $\begin{array}{l}\text { Top Management Support -> Non- } \\
\text { financial Performance }\end{array}$ & 0.091 & 0.059 & 1.542 & $\mathrm{NO}$ \\
\hline $\mathrm{H} 2$ & $\begin{array}{l}\text { Top Management Support -> Financial } \\
\text { Performance }\end{array}$ & -0.106 & 0.065 & $1.647^{*}$ & YES \\
\hline $\mathrm{H} 3$ & $\begin{array}{l}\text { Customer Focus -> } \\
\text { Non-financial Performance }\end{array}$ & -0.006 & 0.074 & 0.081 & $\mathrm{NO}$ \\
\hline $\mathrm{H} 4$ & $\begin{array}{l}\text { Customer Focus }-> \\
\text { Financial Performance }\end{array}$ & 0.085 & 0.073 & 1.172 & $\mathrm{NO}$ \\
\hline $\mathrm{H} 5$ & $\begin{array}{l}\text { Employee Orientation -> } \\
\text { Non-financial Performance }\end{array}$ & 0.051 & 0.077 & 0.668 & $\mathrm{NO}$ \\
\hline H6 & $\begin{array}{l}\text { Employee Orientation -> Financial } \\
\text { Performance }\end{array}$ & -0.012 & 0.079 & 0.155 & $\mathrm{NO}$ \\
\hline $\mathrm{H} 7$ & $\begin{array}{l}\text { Technology Orientation -> Non- } \\
\text { financial Performance }\end{array}$ & 0.384 & 0.067 & $5.729^{* *}$ & YES \\
\hline $\mathrm{H} 8$ & $\begin{array}{l}\text { Technology Orientation -> Financial } \\
\text { Performance }\end{array}$ & 0.433 & 0.072 & $5.981^{* *}$ & YES \\
\hline $\mathrm{H} 9$ & $\begin{array}{l}\text { Entrepreneurial Orientation -> Non- } \\
\text { financial Performance }\end{array}$ & 0.293 & 0.076 & $3.828^{* *}$ & YES \\
\hline $\mathrm{H} 10$ & $\begin{array}{l}\text { Entrepreneurial Orientation }-> \\
\text { Financial Performance }\end{array}$ & 0.311 & 0.074 & $4.206^{* *}$ & YES \\
\hline
\end{tabular}

Note: ${ }^{*} \mathrm{p}<0.05,{ }^{* *} \mathrm{p}<0.01$

\section{Discussion}

The present study was conducted among SMEs in Malaysia with a twofold research objective in mind. First, to examine the relationship between critical success factors and non-financial performance; second, to investigate the relationship between critical success factors and financial performance.

First, the statistical results have underlined that top management support is significantly and positively related to financial performance. Consistent with previous findings, financial performance could be improved if top management emphasizes communicating the mission and vision throughout the entire organization, providing direction for employees to achieve and increase their level of performance (Demirbag et al., 2006; Fotopoulos \& Psomas, 2009; Turkyilmaz et al., 2010). However, the findings of the present study have determined that top management support was not significantly related to non-financial performance. This could be due to the high power distance culture and hierarchical organizational structure in Malaysia, which means employees unlikely to voice their opinions and approach their bosses directly, thus limiting the development of relationship between top management and employees, and open communication required for innovation.

Contrary to expectation, customer focus and employee orientation were not found to have any significant effect on non-financial performance and financial performance. The findings seem to contradict previous researches which contend positive relationship between these success factors and organizational performance (Awan, 2013; de Bussy \& Suprawan, 2012; Nwokah \& Maclayton, 2006; Ziggers \& Henseler, 2015). The nature of the firms studied in the present study provides reasonable justifications for these findings. Although creating satisfied customers are essential for firms to success, customer focus strategy seems to be too costly for small capital SMEs. Today's 
customers are more demanding than ever before, and thus it is increasingly difficult for SMEs to create valuable relationships with the customers in order to improve their performance. On the other hand, small number of employees in SMEs might be the reason which makes employee orientation less relevant in helping firms to achieve superior performance.

The analysis has indicated that technology orientation is significantly and positively related to both non-financial performance and financial performance. As evidenced by previous research, firms that are technology-oriented have better chance to achieve superior performance (AlAnsari et al., 2013; Trainor et al., 2010; Zhou \& $\mathrm{Li}, 2010)$. This is because technology orientation can provides firms with capability to acquire rich technological information and new technologies that are useful for firms to come out with new solutions that are difficult to be imitated by their competitors (Gatignon \& Xuereb, 1997; Grinstein, 2008).

As for entrepreneurial orientation, the results have shown that entrepreneurial orientation is positively related to both nonfinancial performance and financial performance. This result is consistent with previous findings that found that organizational performance could be improved if the firms put a strong emphasis on innovativeness, riskiness, proactiveness, competitive aggressiveness, as well as on autonomy in response to market changes (Gupta \& Batra, 2015; Walter et al., 2006). This is further supported by Jabeen and Mahmood (2014) who state that firms adopting a strong entrepreneurial orientation are willing to take risks and thus they can innovate quickly, which would result in more innovative products and leading to superior performance.

\section{Implications}

This paper recognizes the relationship between the critical success factors determinants as the drivers of the effectiveness and success of organizational performance in Malaysia SMEs.
In continuation hereof, the adoption of the CSFs should not only be seen as a mean to satisfy external stakeholders, but similarly, the CSFs proved to be beneficial in optimizing internal processes of the organization.

From the managerial perspective, this research offers a number of policy implications for SMEs managers and policy makers. The instrument used in this paper will be very useful to policy makers in SMEs as a tool for evaluating the effectiveness of their current organizational practices. Furthermore, SMEs managers should be aware that the intermediating impact of organizational performance (financial and non-financial performance) could only be enhanced by improving the critical success factors determinants. This study can help entrepreneurs, especially SMEs owners who often lack capital, to identify critical success factors, with which they can add most value to their business. The findings of this study suggest that, for the context of SMEs in Malaysia and current business environment, technology orientation and entrepreneurial orientation are the most important factors for entrepreneurs to improve their performance, and therefore entrepreneurs should prioritize their investments in these success factors.

This study contributes to the body of knowledge by demonstrating that different critical success factors have different degrees of impact on organizational performance. The findings show that technology orientation and entrepreneurial orientation are positively related to both non-financial performance and financial performance, while top management support is positively related to financial performance only. In contrast, the results do not support any relationship between customer focus, employee orientation and organizational performance. By comparing several critical success factors in a model, this study revealed the most significant critical success factors that can contribute to better organizational performance. Hence, this study has successfully developed some guidelines for scholars who are interested in this field to further 
test the relationships among these constructs, especially in SMEs and emerging country context.

\section{Limitations and suggestions for future research}

Future studies may replicate this effort with slight modifications. This study has relied primarily on samples of SMEs entrepreneurs in Malaysia. Therefore, it is not certain that the results can be generalized to larger organizations or other countries. Moreover, this study used crosssectional data and thus it can only provide a static perspective on fit. Comparative studies across industries, cultures, and professions, including control variables such as size and industry, should be sought in the future in order to improve understanding on the relationship between constructs included in this study. Besides that, several research approaches that can be conducted, such as case studies, focus group discussions, may permit deeper insights. Wherever possible, future research should endeavor to determine a more holistic quality management model. Research efforts could examine the effect of total quality management critical success factors on organizational performance. Another important avenue for future research is to carry out an indepth interview with the senior management in order to gain more detail information. It is further suggested that research efforts should seek to complement the subjective measures by objective data in order to gain more reliable findings.

\section{Conclusions}

As point of departure in the stated research objectives, it was sought to investigate the critical success factors on the organizational performance (financial and non-financial) of the SMEs Malaysia companies. From the empirical analysis, five critical success factors on organizational performance were analyzed. It was revealed that two (technology orientation and entrepreneurial orientation) out of five proposed CSFs have significantly contributed to the organizational performance of the SMEs. The implication of the empirical analysis indicates that having a high degree of technology orientation has direct impact on the organizational performance. This indicates that to improve the firm performance, it is essential for SMEs to cultivate technology orientation through the active acceptance of new technology. Particularly, having a high degree of entrepreneurial orientation in the SMEs is vital as it wields a positive influence on organizational performance. Entrepreneurial orientation implies it can create competency in the firms that lead to improve performance in areas such as marketing, $\mathrm{R} \& \mathrm{D}$, organizational renewal and delivering new products and services. These findings thus indicate that it may be beneficial for SMEs firms to place special emphasis on technology orientation and entrepreneurial orientation.

\section{References}

Ahire, S. L., \& Golhar, D. Y. (1996). Quality management in large vs. small. Journal of Small Business Management, 34(2), 1-13.

Akter, S., D’Ambra, J., \& Ray, P. (2011). Trustworthiness in mHealth information services: an assessment of a hierarchical model with mediating and moderating effects using Partial Least Squares (PLS). Journal of the American Society for Information Science and Technology, 62(1), 100-116.

Al-Ansari, Y., Altalib, M., \& Sardoh, M. (2013). Technology orientation, innovation and business performance: A study of Dubai SMEs. The International Technology Management Review, 3(1), 1-11.

Al Shaar, E. M., Khattab, S. A., Alkaied, R. N., \& Manna, A. Q. (2015). The effect of top management support on innovation: The mediating role of synergy between organizational structure and information technology. International Review of Management and Business Research, 4(2), 499. 
Ar, I. M., \& Baki, B. (2011). Antecedents and performance impacts of product versus process innovation: Empirical evidence from SMEs located in Turkish science and technology parks. European Journal of Innovation Management, 14(2), $172-206$.

Aron O'C., \& Liem V. N. (2011). Achieving customer satisfaction in services firms via branding capability and customer empowerment. Journal of Services Marketing, 25(7), 489 - 496.

Awan, W. A. (2013). Impact of employee orientation on retention: a case of service sector organizations in Pakistan. Interdisciplinary Journal of Contemporary Research in Business, 5(4), 326-333.

Bagozzi, R. P., \& Yi, Y. (1988). On the evaluation of structural equation models. Academy of Marketing Science, 16(1), 74-94.

Baum, T. (1995). Managing human resources in the European tourism and hospitality industry: a strategic approach. London: Chapman and Hall.

Bernardin, H. J., \& Russell, J. E. A. (1993). Human resource management: an experiential approach. New York: McGraw-Hill.

Blazevic, V., \& Lievens, A. (2004). Learning during the new financial service innovation process: antecedents and performance effects. Journal of Business Research, 57(4), 374-391.

Bryde, D. (2008). Perceptions of the impact of project sponsorship practices on project success. International Journal of Project Management, 26(8), 800-809.

Chen, I. J., Paulraj, A., \& Lado, A. (2004). Strategic purchasing, supply management and firm performance, Journal of Operations Management, 22(5), 505-523.

Chen, J. S., Tsou, H. T., \& Huang, A. Y. H. (2009). Service delivery innovation antecedents and impact on firm performance. Journal of Service Research, 12(1), 36-55.
Chin, W. W. (1998). The Partial least squares approach for structural equation modeling. In G. A. Marcoulides (Ed.), Modern methods for business research (pp. 295-336). NJ: Lawrence Erlbaum.

Chin, W. W. (2010). How to write up and report PLS analyses. In V. Esposito Vinzi, W. W. Chin, J. Henseler, \& H. Wang (Eds.), Handbook of partial least squares: concepts, methods and application (pp. 645-689). Germany: Springer.

Chong, A. Y. L., Chan, F. T. S., \& Sim, O. J. J. (2011). Can Malaysian firms improve organizational innovation performance via SCM? Industrial Management \& Data Systems, 111(3), $410-431$.

Chong, W. K., Shafaghi, M., \& Tan, B. L. (2011). Development of a business-to-business critical success factors (B2B CSFs) framework for Chinese SMEs. Marketing Intelligence \& Planning, 29(5), 517-533.

Covin, J. G., \& Miles, M. P. (1999). Corporate entrepreneurship and the pursuit of competitive advantage. Entrepreneurship: Theory \& Practice, 23(3), 47-63.

Covin, J. G., \& Slevin, D. (1989). Strategic management of small firms in hostile and benign environments. Strategic Management Journal, 10(1), 75-87.

Das, A., Paul, H., \& Swierczek, F. (2008). Developing and validating total quality management (TQM) constructs in the context of Thailand's manufacturing industry. Benchmarking. An International Journal, 15(1), 52-72.

Day, G. S. (1994). The capabilities of marketdriven organizations. Journal of Marketing, 58(4), 37-52.

de Bussy, N. M., \& Suprawan, L. (2012). Most valuable stakeholders: the impact of employee orientation on corporate financial 
performance. Public Relations Review, 38(2), 280-287.

Deming, W. E. (1986). Out of the crisis. Cambridge, MA: MIT Press.

Demirbag, H., Tatoglu, E., Tekinkus, M., \& Zaim, S. (2006). An analysis of the relationship between TQM implementation and organizational performance: Evidence from Turkish SMEs. Journal of Manufacturing Technology Management, 1(6), 829-847.

Fernandes, A. A. C. M., Lourenço, L. A. N., \& Silva, M. J. A. M. (2014). Influence of Quality Management on the Innovative Performance/Influência da Gestão da Qualidade no Desempenho Inovador/Influencia de la gestión de la calidad en el desempeño innovador. Revista Brasileira de Gestão de Negócios, 16(53), 575-593.

Flynn, B. B., Schroeder, R. G., \& Sakakibara, S. (1995). The impact of quality management practices on performance and competitive advantage. Decision Sciences, 26(5), 659-692.

Fornell, C., \& Larcker, D. F. (1981). Evaluating structural equation models with unobservable variables and measurement error. Journal of Marketing Research, 18, 39-45.

Fotopoulos, C. V., \& Psomas, E. L. (2009). The structural relationships between TQM factors and organizational performance. The Total Quality Management Journal, 22(5), 539-552.

Ganeshasundaram, R., \& Henley, N. (2007). Decision research correlates directly with better business performance. Marketing Intelligence \& Planning, 25(1). 45-65.

Garrett, R. P., \& Neubaum, D. O. (2013). Top management support and Initial strategic assets: A dependency model for internal corporate venture performance. Journal of Product Innovation Management, 30(5), 896-915.
Gatignon, H., \& Xuereb, J. M. (1997). Strategic orientation of firm new product performance. Journal of Marketing Research, 34(1), 77-90.

Gefen, D., Straub, D. W., \& Boudreau, M. C. (2000). Structural equation modeling and regression: guidelines for research practice. Communications of the AIS, 4(7), 1-76.

Griffin, K. (2003). Economic globalization and institutions of global governance. Development and Change, 34(5), 789-807.

Grinstein, A. (2008). The relationships between market orientation and alternative strategic orientations: a meta-analysis. European Journal of Marketing, 42(1/2), 115-134.

Gronroos, C. (2004). The relationship marketing process: communication, interaction, dialogue, value. Journal of Business and Industrial Marketing, 19(2), 99-113.

Gupta, V. K., \& Batra, S. (2015). Entrepreneurial orientation and firm performance in Indian SMEs: Universal and contingency perspectives. International Small Business Journal, 1-23.

Hair, J. F., Black, W. C., Babin, B. J., \& Anderson, R. E. (2010). Multivariate Data Analysis (7th ed.): Prentice Hall.

Halawi, L., \& McCarthy, R. (2008). Measuring students perceptions of blackboard using the technology acceptance model: A PLS approach. E-learning, 26(2), 18.

Halim, H. A., Ahmad, N. H., \& Ramayah, T. (2013). Manoeuvring the rough commercial landscape through outsourcing: repositioning Malaysian SMEs. In P. O. de Pablos (Ed.), International business strategy and entrepreneurship: an information technology perspective: an information technology perspective (pp. 41-51). US: Business Science Reference.

Hambrick, D. C., \& Mason, P. A. (1984). Upper echelons: the organization as a reflection of its 
top managers. Academy of Management Journal, 15(3), 193-206.

Hendricks, K. B.; Singhal, V. R. (1997). Does implementing an effective TQM programme actually improve operating performance. Management Science, 43(9), 1258-1274.

Ho, T. C., Ahmad, N. H., \& Ramayah, T. (2016). Competitive capabilities and business performance among manufacturing SMEs: Evidence from an emerging economy, Malaysia. Journal of AsiaPacific Business, 17(1), 37-58.

Hung, R. Y. Y., Lien, B. Y. H., Fang, S. C., \& McLean, G. N. (2010). Knowledge as a facilitator for enhancing innovation performance through total quality management. Total Quality Management, 21(4), 425-438.

Iqbal, S. M. J., Long, C. S., Fei, G. C., Ba'ith, S. M. L. A., \& Bukhari, S. (2015). Moderating effect of top management support on relationship between transformational leadership and project success. Pakistan Journal of Commerce and Social Sciences, 9(2), 540-567.

Ireland, R. D., Hitt, M. A., \& Sirmon, D. G. (2003). A model of strategic entrepreneurship: the construct and its dimensions. Journal of Management, 29(6), 963-990.

Jabeen, R., \& Mahmood, R. (2014). Effect of external environment on entrepreneurial orientation and business performance relationship. Social and Basic Sciences Research Review, 2(9), 394-403.

Kaplan, R. S., \& Norton, D. P. (1996). The balanced scorecard: Translating strategy into action. Harvard Business Review Press.

Kim, N., Im, S., \& Slater, S. F. (2013). Impact of knowledge type and strategic orientation on new product creativity and advantage in hightechnology firms. Journal of Product Innovation Management, 3O(1), 136-153.
Kirca, A. H., Jayachandran, S., \& Bearden, W. O. (2005). Market orientation: A meta-analytic review and assessment of its antecedents and impact on performance. Journal of marketing, 69(2), 24-41.

Lee, D., Choi, S., \& Kwak, W. (2015). The effects of four dimensions of strategic orientation on firm innovativeness and performance in emerging market small- and medium-size enterprises. Emerging Markets Finance and Trade, 50(5), 78-96.

Lee, S. M., Kim, S. T., \& Choi, D. (2012). Green supply chain management and organizational performance. Industrial Management \& Data Systems, 112(8), 1148-1180

Liu, H., Ke, W., Wei, K. K., \& Hua, Z. (2013). Effects of supply chain integration and market orientation on firm performance: Evidence from China. International Journal of Operations \& Production Management, 33(3), 322-346.

Lo, M. C., Mohamad, A. A., T. Ramayah, \& Wang, Y. C. (2015). Examining the effects of leadership, market orientation and leader member exchange (LMX) on organizational performance. Inzinerine Ekonomika- Engineering Economics, 26(4), 409-421.

Lumpkin, G. T., \& Dess, G. G. (1996). Clarifying the entrepreneurial orientation construct and linking it to performance. Academy of Management Review, 21, 135-172.

Mu, J., \& Benedetto, C. A. D. (2011). Strategic orientations and new product commercialization: mediator, moderator, and interplay. R\&D Management, 41(4), 337-359.

Narver, J. C., \& Slater, S. F. (1990). The effect of a market orientation on business profitability. Journal of Marketing, 54(5), 20-35.

Noble, C. H., Sinha, R. K., \& Kumar, A. (2002). Market orientation and alternative strategic orientations: A longitudinal assessment of 
performance implications. Journal of Marketing, $66(4), 25-39$.

Noe, R. A., \& Wilk, S. L. (1993). Investigation of the factors that influence employee's participation in development activities. Journal of Applied Psychology, 78(22), 1291-1302.

Nwokah, N. G., \& Maclayton, D. W. (2006). Customer focus and business performance: The study of food and beverages organizations in Nigeria. Measuring Business Excellence, 10(4), 65-75.

Podsakoff, P. M., MacKenzie, S. B., Lee, J. Y., \& Podsakoff, N. P. (2003). Common method biases in behavioral research: A critical review of the literature and recommended remedies. Journal of applied psychology, 88(5), 879.

Powell, T. (1995). Total quality management as competitive advantage: A review and empirical study. Strategic Management Journal, 16(1): 5-37.

Prieto, I. M., \& Revilla, E. (2006). Learning capability and business performance: A nonfinancial and financial assessment. The Learning Organization, 13(2), 166-185.

Rauch, A., \& Frese, M. (2000). Psychological approaches to entrepreneurial success: A general model and an overview of findings. International Review of Industrial and Organizational Psychology, 15, 101-142.

Rauch, A., Wiklund, J., Lumpkin, G. T., \& Frese, M. (2009). Entrepreneurial orientation and business performance: An assessment of past research and suggestions for the future. Entrepreneurship Theory and Practice, 33(3), 761-787.

Ringle, C. M., Wende, S., \& Will, A. (2005). SmartPLS 2.O. Hamburg: SmartPLS, http://www. smartpls.de.

Salaheldin, I. (2009). Critical success factors for TQM implementation and their impact on performance of SMEs. International Journal of
Productivity and Performance Management, 58(3), 215-237.

Saravanan, R., \& Rao, K. (2006). Development and validation of an instrument for measuring total quality service. Total Quality Management and Business Excellence, 17(6), 733-749.

Sexton, D. L., \& Upton. N. B. (1987). Evaluation of an innovative approach to teaching entrepreneurship. Journal of Small Business Management, 25(1), 35- 43.

Simon, A., Bartle, C., Stockport, G., Smith, B., Klobas, J. E., \& Sohal, A. (2015). Business leaders' views on the importance of strategic and dynamic capabilities for successful financial and non-financial business performance. International Journal of Productivity and Performance Management, 64(7), 908-931.

Slack, N., Chambers, S., \& Johnston, R. (2010). Operations management. Prentice Hall.

Slater, S. F., Hult, G. T. M., \& Olson, E. M. (2010). Factors influencing the relative importance of marketing strategy creativity and marketing strategy implementation effectiveness. Industrial Marketing Management, 39(4), 551-559.

Slater, S. F., \& Narver, J. C. (1998). Research notes and communications customer-led and marketoriented: Let's not confuse the two. Strategic management journal, 19(10), 1001-1006.

Song, X. M., \& Parry, M. E. (1997). A crossnational comparative study of new product development processes: Japan and the United States. Journal of Marketing, 61(2), 1-18.

Sun, H. (2000). Total quality management, ISO 9000 and performance improvement. International Journal of Quality and Reliability Management, 17(2), 168-179.

Tehseen, S., Sajilan, S., Ramayah, T., \& Gadar, K. (2015). An Intra-Cultural Study of Entrepreneurial Competencies and SMEs Business Success in 
Whole Sale and Retail Industries of Malaysia:-A Conceptual Model. Review of Integrative Business and Economics Research, 4(3), 33.

Tenenhaus, M., Esposito Vinzi, V., Chatelin, Y. M., \& Lauro, C. (2005). PLS path modeling, Computational Statistics \& Data Analysis, 48(1), 159-205.

Trainor, K., Rapp, A., Beitelspacher, L.S., \& Schillewaert, Niels. (2010). Integrating information technology and marketing: And examination of drivers and outcomes of e-marketing capability. Industrial Marketing Management, 4O(1), 1-13.

Turkyilmaz, A., Tatoglu, E., Zaim, S., \& Ozkan, C. (2010). TQM practices and business performance in SMEs. In V. Esposito Vinzi, W. W. Chin, J. Henseler, \& H. Wang (Eds.), Handbook of partial least squares (pp. 605-621). Verlag: Springer.

Umble, E. J., Haft, R. R., \& Umble, M. M. (2003). Enterprise resource planning: implementation procedures and critical success factors. European Journal of Operational Research, 146, 241-257.

Utsch, A., \& Rauch, A. (2000). Innovativeness and initiative as mediators between achievement orientation and venture performance. European Journal of Work and Organizational Psychology, 9(1), 45-62.

Vazquez, M. V., Silva, F. J. C., \& Ruiz, D. M. (2012). Does the firm's market innovation behaviour influence innovation's success? Management Decision, 50(8), 1445-1464.

Vyas, V., Raitani, S., Roy, A., \& Jain, P. (2015). Analysing critical success factors in small and medium enterprises banking. World Review of Entrepreneurship, Management and Sustainable Development, 11(1), 106-123.

Wales, W. J., Parida, V., \& Patel, P. C. (2013). Too much of a good thing? Absorptive capacity, firm performance, and the moderating role of entrepreneurial orientation. Strategic Management Journal, 34(5), 622-633.

Walter, A., Auer, M., \& Ritter, T. (2006). The impact of network capabilities and entrepreneurial orientation on university spin-off performance. Journal of Business Venturing, 21, 541-567.

Wetzels, M., Odekerken-Schroder, G., van Oppen, C. (2009). Using PLS path modeling for assessing hierarchical construct models: guidelines and empirical illustration. MIS Quarterly, 33(1), 177-196.

Wiklund, J., \& Shepherd, D. (2005). Entrepreneurial orientation and small business performance: a configurationally approach. Journal of Business Venturing, 20, 71-91.

Yusof, S., \& Aspinwall, E. (2000). Critical success factors in small and medium enterprises: survey results. Total Quality Management, 11(4), 248-462.

Zebal, M. A., \& Goodwin, D. R. (2011). Market orientation in a developing nation antecedents, consequences and the moderating effect of environmental factors. Marketing Bulletin, 22(1), 1-23.

Zhang, J. (2010). Employee orientation and performance: An exploration of the mediating role of customer orientation. Journal of Business Ethics, 91, 111-121.

Zhou, K. Z., \& Li, C. B. (2010). How strategic orientations influence the building of dynamic capability in emerging economies. Journal of Business Research, 63(3), 224-231.

Zhou, K. Z., Yim, C. K., \& Tse, D. K. (2005). The effects of strategic orientations on technologyand market-based breakthrough innovations, Journal of Marketing, 69, 42-60.

Ziggers, G. W., \& Henseler, J. (2015). The reinforcing effect of a firm's customer orientation and supply-base orientation on performance. Industrial Marketing Management, $52,18-26$. 


\section{Supporting Agencies:}

This research was supported by Universiti Malaysia Sarawak and Ministry of Higher Education, Malaysia under the Exploratory Research Grant Scheme [ERGS/SS05 (01)/1013/2013(10)].

\section{About the authors:}

1. May Chiun Lo, PhD in Management from Universiti Sains Malaysia, Malaysia. E-mail: mclo@unimas.my

2. Yin Chai Wang, PhD in GIS from Universiti Sains Malaysia, Malaysia. E-mail: ycwang@unimas.my

3. Constance Rinen Justin Wah, MSc in Business Administration, Universiti Malaysia Sarawak, Malaysia. E-mail: rwjconstance@unimas.my

4. T. Ramayah, MSc in Business Administration, Universiti Sains Malaysia, Malaysia.

E-mail: ramayah@usm.my

\section{Contribution of each author:}

\begin{tabular}{|c|c|c|c|c|}
\hline Contribution & May Chiun Lo & Yin Chai Wang & $\begin{array}{l}\text { Constance Rinen } \\
\text { Justin Wah }\end{array}$ & T. Ramayah \\
\hline 1. Definition of research problem & $\sqrt{ }$ & & & \\
\hline $\begin{array}{l}\text { 2. Development of hypotheses or research questions } \\
\text { (empirical studies) }\end{array}$ & $\sqrt{ }$ & & & \\
\hline 3. Development of theoretical propositions (theoretical work) & $\sqrt{ }$ & & $\sqrt{ }$ & \\
\hline 4. Theoretical foundation / Literature review & & & $\sqrt{ }$ & \\
\hline 5. Definition of methodological procedures & & & & $\sqrt{ }$ \\
\hline 6. Data collection & $\sqrt{ }$ & $\sqrt{ }$ & & \\
\hline 7. Statistical analysis & $\sqrt{ }$ & & & $\sqrt{ }$ \\
\hline 8. Analysis and interpretation of data & & $\sqrt{ }$ & & $\sqrt{ }$ \\
\hline 9. Critical revision of the manuscript & & $\sqrt{ }$ & & \\
\hline 10. Manuscript writing & $\sqrt{ }$ & & $\sqrt{ }$ & \\
\hline
\end{tabular}

